\title{
Brain morphology and immunohistochemical localization of the gonadotropin-releasing hormone in the bluefin tuna, Thunnus thynnus
}

\author{
G. Palmieri, ${ }^{1}$ F. Acone, ${ }^{1}$ S. Desantis, ${ }^{2}$ A. Corriero, ${ }^{2}$ G. Ventriglia, ${ }^{2}$ P. Addis, ${ }^{3}$ S. Genovese, ${ }^{4}$ \\ A. Aprea, ${ }^{2}$ D. Spedicato, ${ }^{2}$ M. Losurdo, ${ }^{2}$ M. Deflorio, ${ }^{2}$ A. Di Summa, ${ }^{2}$ G. De Metrio ${ }^{2}$
} ${ }^{1}$ Department of Animal Biology, University of Sassari, Sassari; ${ }^{2}$ Department of Animal Health and Wellbeing, University of Bari, Valenzano; ${ }^{3}$ Department of Animal Biology and Ecology, University of Cagliari, Cagliari; " Institute for Coastal Marine Environment, National Research Council, Mazara del Vallo (TP), Italy

C2008 European Journal of Histochemistry

The present study was focused on the morphology of the diencephalic nuclei (likely involved in reproductive functions) as well as on the distribution of GnRH (gonadotropin-releasing hormone) in the rhinencephalon, telencephalon and the diencephalon of the brain of bluefin tuna (Thunnus thynnus) by means of immunohistochemistry. Bluefin tuna has an encephalization quotient (QE) similar to that of other large pelagic fish. Its brain exhibits well-developed optic tecta and corpus cerebelli. The diencephalic neuron cell bodies involved in reproductive functions are grouped in two main nuclei: the nucleus preopticus-periventricularis and the nucleus lateralis tuberis. The nucleus preopticus-periventricularis consists of the nucleus periventricularis and the nucleus preopticus consisting of a few sparse multipolar neurons in the rostral part and numerous cells closely packed and arranged in several layers in its aboral part. The nucleus lateralis tuberis is located in the ventral-lateral area of the diencephalon and is made up of a number of large multipolar neurones.

Four different polyclonal primary antibodies against salmon (s) GnRH, chicken (c) GnRH-II (cGnRH-II 675, cGnRH-II 6) and sea bream (sb)GnRH were employed in the immunohistochemical experiments. No immunoreactive structures were found with anti sbGnRH serum. sGnRH and cGnRH-II antisera revealed immunoreactivity in the perikarya of the olfactory bulbs, preopticus-periventricular nucleus, oculomotor nucleus and midbrain tegmentum. The nucleus lateralis tuberis showed immunostaining only with anti-sGnRH serum. Nerve fibres immunoreactive to $\mathrm{cGnRH}$ and $\mathrm{sGnRH}$ sera were found in the olfactory bulbs, olfactory nerve and neurohypophysis. The significance of the distribution of the GnRHimmunoreactive neuronal structures is discussed.

Key words: bluefin tuna (Thunnus thynnus); brain; gonadotropin-releasing hormone; immunohistochemistry.

Correspondence: Gregorio De Metrio,

Department of Animal Health and Well-being,

University of Bari, Valenzano, Italy

E-mail: g.demetrio@veterinaria.uniba.it

Paper accepted on January 11, 2008

European Journal of Histochemistry

2008; vol. 52 issue 1 (Jan-Mar): 19-28
$G$ onadotropin-releasing hormone $(\mathrm{GnRH})$ is a key regulator of the pituitary-gonadal axis as it stimulates both synthesis and release of teleost pituitary gonadotropin (GTH) (Peter, 1983; Okuzawa and Kobayashi, 1999; Zohar and Mylonas, 2001).

Fourteen forms of GnRH have so far been identified in different vertebrate species (Pham et al., 2006). In teleost fish, $8 \mathrm{GnRH}$ variants have been identified, although two or three of the GnRH forms co-exist in the brain albeit distributed differently (Pham et al., 2006). Among the Pleuronectiforms and Perciformes, sea bream (sb)GnRH-producing cell bodies in the preoptic area project their axons mainly to the pituitary, whereas salmon sGnRHand chicken cGnRH-producing cells connect different areas of the brain through their axons, which, however, do not project to the pituitary (White et al., 1995; Gonzalez-Martínez et al., 2001; Amano et al., 2002).

The localization of $\mathrm{GnRH}$-expressing neurons by means of immunohistochemistry in many of the teleost species studied so far has shown that GnRH neurons are distributed in the tegmentum of the midbrain, in the anterior telencephalon (terminal nerve included), as well as in the caudal telencephalon-preoptic region and in the rostral hypothalamus (reviewed by Lethimonier et al., 2004).

Reproductive dysfunctions are often exhibited by fish reared in captivity ascribable to captivityinduced stress (Mylonas and Zohar, 2001), and are due to the absence of $\mathrm{GnRH}$ release. The attempts in Japan to reproduce Pacific bluefin tuna (Thunnus orientalis) in captivity in the last decade produced inconsistant results (Doumenge, 1996; Lioka et al., 2000). Recently, spawning of Atlantic bluefin tuna (Thunnus thynnus) reared in captivity in the Mediterranean has been obtained by the administration of a GnRH agonist (Corriero et al., 2007; Mylonas et al., 2007). 
To increase the possibility of success in bluefin tuna domestication, a better understanding of the reproductive biology of this fish is required, with special focus on the brain-pituitary-gonad axis.

The aim of this paper was i) to provide data on the gross morphology of bluefin tuna brain; ii) to describe the main diencephalic nuclei involved in reproductive function; iii) to immunolocalize, in both the forebrain and midbrain, the neurons responsible for $\mathrm{GnRH}$ synthesis.

\section{Materials and Methods}

\section{Sampling}

Both brain and pituitary were collected from 18 sexually mature bluefin tuna killed during the period of natural spawning of the species (June-July, 2005 and 2006) at several locations in the Mediterranean Sea. The total body mass and brain mass of each specimen were measured to the nearest $\mathrm{kg}$ and to $0.01 \mathrm{~g}$, respectively.

Samples were fixed in 10\% buffered formalin for $24 \mathrm{~h}$, dehydrated through graded alcohols, cleared in xylene and embedded in paraffin wax. Twelve- or five- $\mu \mathrm{m}$ thick sections were cut for morphology or immunohistochemistry investigations, respectively.

\section{Encephalization quotient and morphology}

The encephalization quotient (QE) was calculated as the ratio of actual brain size to expected brain size using the formula:

$$
\mathrm{QE}=\mathrm{EAEE^{-1 }}
$$

where $\mathrm{EA}=$ actual brain mass and $\mathrm{EE}=$ expected brain mass.

The EE for bluefin tuna was calculated by the allometric equation for the brain mass to body mass relationship $\left(\log _{10}\right.$ brain mass $=0.5301$ $\log _{10}$ body mass ${ }^{0.8735}$ ) reported by Lisney and Collin (2006).

Morphological investigations were performed by haematoxylin-eosin or Nissl stainings and Bielschowsky silver technique modified by Servier and Munger (1965). Neuron size was determined on histological slides by a Quantimet 500W (Leica, Cambridge, U.K.) image analyser by measuring the minor and major axis of at least 100 cell bodies for each cell type. Cell body size is given as mean \pm S.E.

\section{Immunohistochemistry}

De-waxed and re-hydrated tissue sections were immersed in $3 \% \mathrm{H}_{2} \mathrm{O}_{2}$ for $10 \mathrm{~min}$ to suppress endogenous peroxidase activity and then rinsed with distilled water and phosphate buffered saline (PBS, $0.01 \mathrm{M}, \mathrm{pH}$ 7.4) containing $0.15 \mathrm{M} \mathrm{NaCl}, 1 \%$ bovine serum albumin (BSA) and $0.5 \%$ Triton $X-$ 100. Non-specific binding sites for immunoglobulins were blocked by incubation for 30 min with $5 \%$ normal goat serum (NHS) in PBS containing $1 \%$ BSA. Sections were then incubated for 15-24 $\mathrm{h}$ at $4^{\circ} \mathrm{C}$ in a moist chamber with nine different dilutions (1:100, 1:500, 1:1000, 1:1500, 1:2000, 1:2500, $1: 3000,1: 4000,1: 5000)$ of polyclonal primary antisera against salmon(s) GnRH, chicken(c)GnRH and sea bream(sb)GnRH, used to determine the optimal working dilution. Anti sGnRH (lot n. 1667) and anti cGnRH (lot n. 675) were kindly supplied by R. P. Millar; anti cGnRH (lot n. 6) and anti sbGnRH (lot n. 691) were kindly provided by $M$. Amano.

All antisera were diluted in 5\% BSA/0.01 M PBS/0.5\% Triton X-100, pH 7.4. The resulting suitable working dilutions (no background) for each antiserum are given in Table 1 . The slices were rinsed in Triton-PBS for 15 min and incubated with biotinylated secondary antibody for $30 \mathrm{~min}$ to be washed in PBS and re-incubated in avidin-biotinperoxidase complex ( $A B C$ ) (Vector, Burlingame, $C A$ ). Peroxidase activity was visualised by 10-min. incubation with Vector DAB Peroxidase Substrate Kit (Vector, Burlingame, CA), which produces a brown precipitate. Finally, the sections were counterstained with hematoxylin, dehydrated and mounted.

Negative controls were performed by: (1) replacement of primary antibody with NGS, and (2) omission of primary antibody.

Table 1. Anti-GnRH sera immunoreactivity of the bluefin tuna diencephalons.

\begin{tabular}{lcccc}
\hline Antisera against & Lot No. & Dilution & $\begin{array}{c}\text { PO-PV } \\
\%(S . D .)\end{array}$ & $\begin{array}{c}\text { LT } \\
\% \text { (S.D.) }\end{array}$ \\
\hline salmonGnRH & $1667^{*}$ & $1: 1500$ & $25(8)$ & $43(9)$ \\
chickenGnRH-II & $675^{*}$ & $1: 2500$ & $47(12)$ & - \\
chickenGnRH-II & $6^{* *}$ & $1: 3000$ & $43(6)$ & - \\
seabreamGnRH & $691^{* *}$ & $1: 5000$ & - & - \\
& & & &
\end{tabular}

PO-PV, nucleus preopticus-periventricularis; LT, lateralis tuberis nucleus; S.D., standard deviation; -, no immunostaining; *, provided by R.P. Millar (MRC, Edinburgh, UK);

**, provided by M. Amano (Kitasato University, Japan). 
Series of four sections were cut every $50 \mu \mathrm{m}$ of tissue; in each series, one of the sections was stained with one of the four antisera. For each primary antiserum, the percentage of immunoreactive cells was estimated by counting the cells with a clearly visible nucleus in 18 immunostained sections.

The count was performed using light microscopy fields captured at 20x magnification and digitalized with a Quantimet 500W image analyser. Data are given as means \pm standard deviation.

\section{Results}

\section{Encephalization quotient and gross brain mor- phology}

The mean brain mass (EA) of the bluefin tuna sampled was $6.52 \pm 1.78 \mathrm{~g}$ and the mean body mass was $97.1 \pm 19.8 \mathrm{~kg}$. Based on the brain mass to body mass relationship obtained for several fish species by Lisney and Collin (2006), the expected brain mass (EE) of the bluefin tuna specimens sampled in the present investigation was calculated to be 9.25 g. Therefore, the $Q E$ is $<1$ i.e. 6.52/9.25 $=0.71$.

The dorsal-lateral and ventral views of the bluefin tuna brain are shown in Figure 1. The olfactory bulbs are not well developed and, in fact, are attached to the rostral-ventral part of the olfactory lobes. The optic tecta are well developed and exhibit a deep groove. The corpus cerebelli, which displays a remarkable rostral-caudal extension dorsal to the optic tecta up to the medulla oblongata, exhibits an evident external folding. The octavolateralis regions, the eminentia granularis and the crista cerebelli are also well developed. The ventral view of the brain is characterized by a very large hypophysis caudally followed by pre-eminent hypothalamic inferior lobes.

\section{Morphology of diencephalic nuclei putatively involved in reproductive functions}

The nucleus preopticus-periventricularis is localized in the diencephalon starting from its rostral end where it covers the inner surface of the ependyma lining the wall of the relevant ventricle (III ventricle or median cavity) (Figure 2). This nucleus consists of a few sparse neurons in the rostral part, whereas its aboral part is constituted by numerous cells closely packed and arranged in several layers (the nucleus periventricularis itself) (Figure 2). The ventral part of the nucleus periventricularis bends
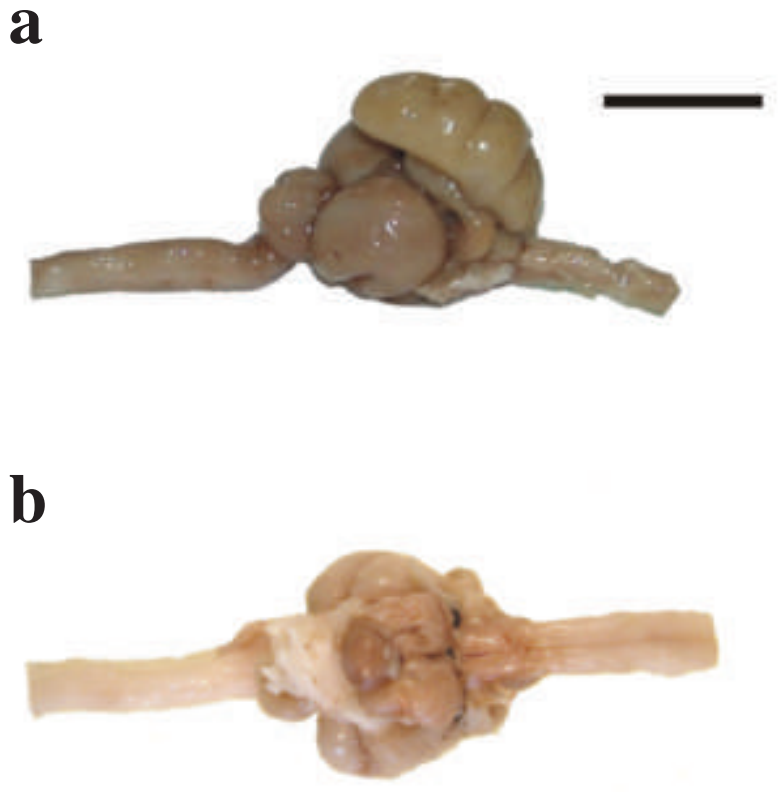

Figure 1. Photographs of bluefin tuna brain. a) dorso-lateral aspect; b) ventral aspect. Bar $=2 \mathrm{~cm}$.

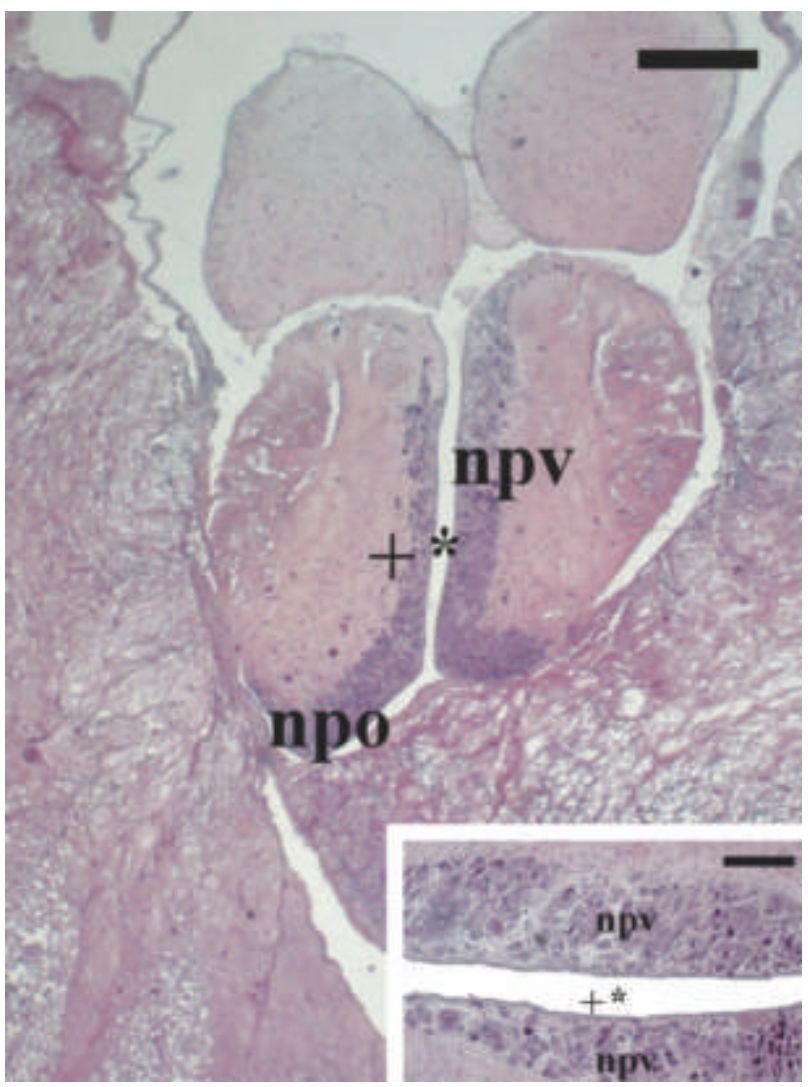

Figure 2. Micrographs of bluefin tuna brain showing the nucleus periventricularis, the nucleus preopticus and the cavity of the third ventricle (bar $=\mathbf{5 0 0} \boldsymbol{\mu m}$ ). Inset: higher magnification of the nucleus periventricularis (bar = $100 \mu \mathrm{m}$ ). Asterisk, cavity of the third ventricle; npo, nucleus preopticus; npv, nucleus periventricularis. Haematoxylin-Eosin staining. 
laterally and forms a $90^{\circ}$ angle at about $200 \mu \mathrm{m}$ from its rostral end, thus giving rise to the preopticus part of the nucleus preopticus-periventricularis (the nucleus preopticus itself) (Figure 2). The preopticus component of the nucleus extends aborally for about $700 \mu \mathrm{m}$ and, beyond its caudal end, the periventricularis nucleus can still be observed for about 120-150 $\mu \mathrm{m}$. This most caudal end of the nucleus periventricularis borders only with the dorsal wall of the ventricle. As a whole, the nucleus preopticus-periventricularis is L-shaped; its vertical component being represented by the nucleus periventricularis and its horizontal one by the nucleus preopticus which owes its name to the fact that it is placed dorsally to the optic chiasm.

The nucleus preopticus-periventricularis is made up of multipolar neurons whose perikaryon is usually ellipsoidal in shape (Figure 2). There exist two
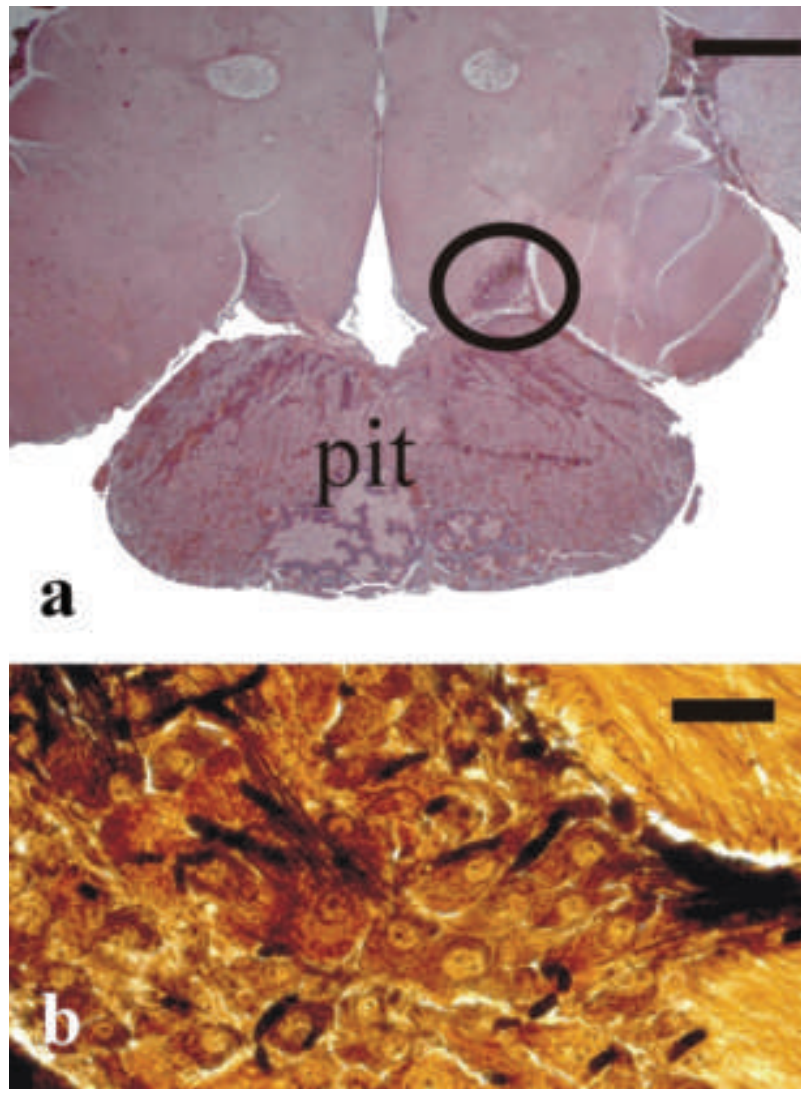

Figure 3. Micrographs of bluefin tuna brain. a) Section passing through the ventral area of the diencephalon showing the nucleus lateralis tuberis, the pituitary peduncle and the pituitary gland. Haematoxylin-Eosin staining. Bar $=1 \mathrm{~mm}$. b) Particular of the nucleus lateralis tuberis showing multipolar neurons interspersed in a close net of blood capillaries. The circle indicates the localization of the nucleus lateralis tuberis; pit, pituitary gland. Bielschowsky silver technique modified by Servier and Munger (1965). Bar $=15 \mu \mathrm{m}$.

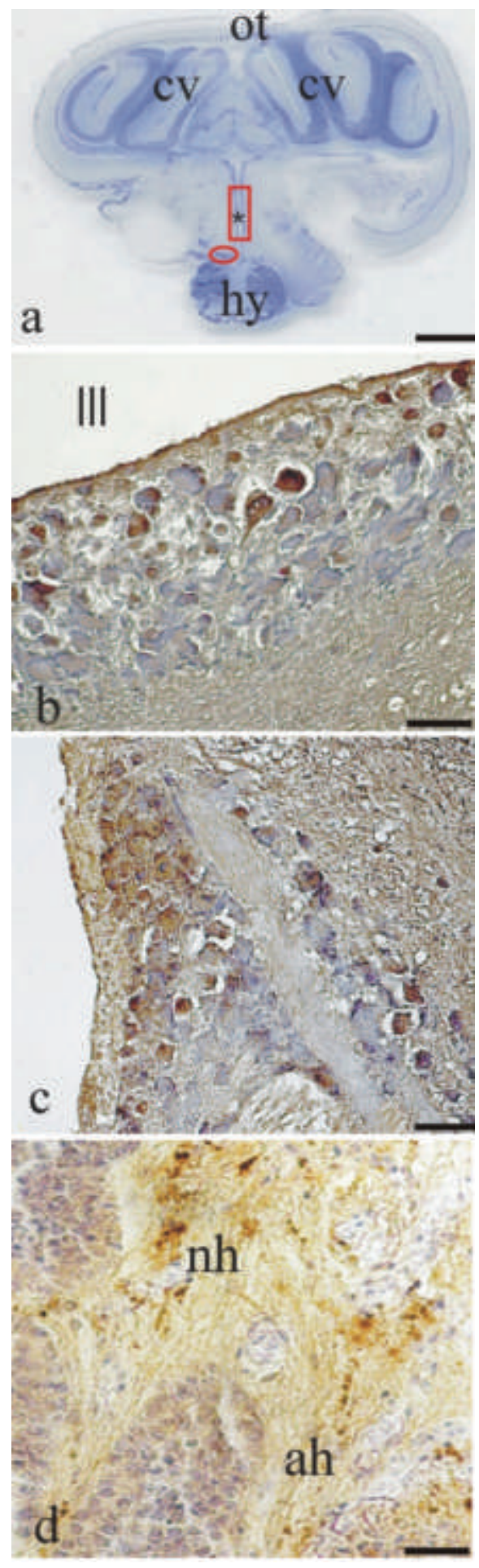

Figure 4. a) Light micrograph of a transverse section of postchiasmatic bluefin tuna brain showing preopticus-periventricularis nucleus (rectangular marked zone) and nucleus lateralis tuberis (circled area) and hypophysis. Nissl staining. Bar $=2$ $\mathrm{mm}$. b) Anti sGnRH positive neurons in the nucleus preopticusperiventricularis and in the nucleus lateralis tuberis. Bar $=16$ $\mu \mathrm{m}$. c) Anti cGnRH II positive neurons in the nucleus preopticus-periventricularis and in the nucleus lateralis tuberis. Bar = $15 \mu \mathrm{m}$. d) Pituitary gland showing GnRH-containing fibres in the neurohypophysis. Bar $=22 \mu \mathrm{m}$. ah, adenohypophysis; cv, cerebelli valvula; hy, hypophysis; nh, neurohypophysis; ot, opticum tectum, asterisk and III, cavity of the third ventricle. 
distinct neuron populations in terms of cell size: i) small cells with a minor axis of $10.5 \pm 2.5 \mu \mathrm{m}$ and a major axis of $18.0 \pm 4.1 \mu \mathrm{m}$; ii) large cells with a minor axis of $22.3 \pm 4.5 \mu \mathrm{m}$ and a major axix of $32.7 \pm 6.9 \mu \mathrm{m}$. These neurons, usually arranged in 36 layers, are interspersed in a close net of blood capillaries (Figure 2) and exhibit a characteristic topographic distribution within the nucleus. In the vertical part of the nucleus (nucleus periventricularis), both large and small neurons occur with the largest ones being pre-eminent. In the horizontal component of the nucleus (nucleus preopticus), only the smaller cell type can be found.

The nucleus lateralis tuberis is located in the ventral-lateral area of the diencephalon, where the nerve fibres constituting the pituitary peduncle emerge from the diencephalon itself (Figure $3 \mathrm{a}, \mathrm{b}$ ). This nucleus, constituted by a certain number of large multipolar neurons with a minor axis of $21.8 \pm 5.5$ $\mu \mathrm{m}$ and a major axis of $33.3 \pm 6.4 \mu \mathrm{m}$, exhibits a rostral-caudal extension of about $1.5 \mathrm{~mm}$.

\section{Immunohistochemistry}

Of the antisera used, only anti sbGnRH serum did not show immunoreactivity with the bluefin tuna diencephalic nuclei (Table 1). Immunostaining mainly occurred in the neuronal perikarya. Anti sGnRH 1667 serum immunoreacted with 20\%$30 \%$ of the perikarya in the preopticus-periventricularis nucleus (Figure $4 a, b$ ) and with $40 \%$ of the neurons of the nucleus lateralis tuberis (Figure $4 \mathrm{a}$, c). Anti cGnRH-II 675 and anti cGnRH-II 6 immunostained around $50 \%$ of neurons in the preopticus-periventricularis nucleus. These antisera did not immunoreact with the lateralis tuberis area.

Differences in both distribution and size of the immunoreactive perikarya were observed. Anti sGnRH- and anti cGnRH-positive cells were mainly found in the preopticus and caudal zone of the periventricularis nucleus. Anti sGnRH immunoreactive neurons were smaller than anti cGnRH ones.

A fascicle of anti GnRH immunoreactive fibres streamed ventro-laterally to the preopticus area running toward the pituitary where GnRH-like immunoreactive fibres were observed (Figure 4d).

Anti cGnRH and anti sGnRH immunostained some perikarya in the nucleus of the oculomotor nerve (Figure $5 \mathrm{a}, \mathrm{b}$ ), but no immunostaining was observed in the oculomotor nerve fibres. GnRHlike neurons were also found in a side zone of the anterior midbrain tegmentum (Figure $6 a, b$,). In
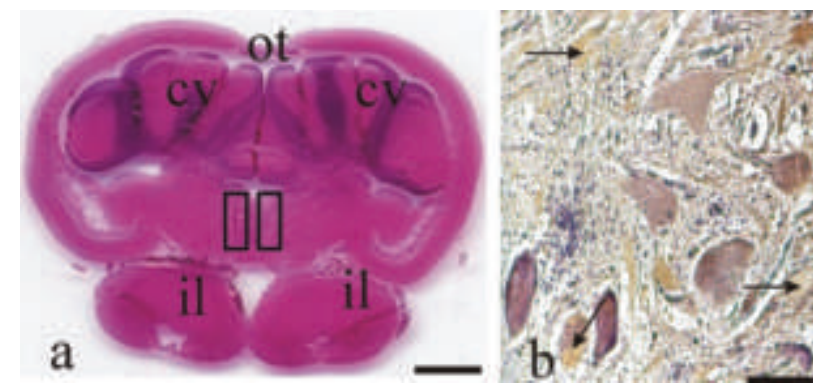

Figure 5. a) Low magnification of a transverse section of bluefin tuna brain showing the oculomotor nucleus sites (marked square zones). Haematoxilyn-Eosin staining. Bar $=2 \mathrm{~mm}$. b) Anti cGnRH II neurons in the oculomotor nucleus. Bar $=\mathbf{7 0} \mu \mathrm{m}$. cv, cerebelli valvula; il, inferior lobe; ot, opticum tectum; arrow: immuno-reactive cells.

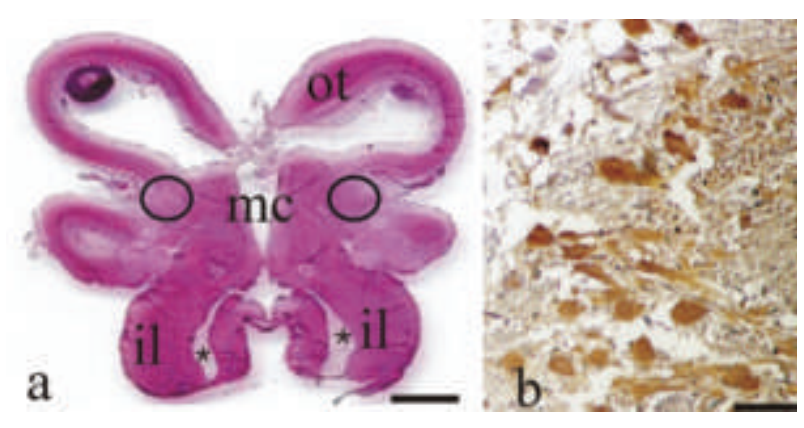

Figure 6. a) Low magnification of a transverse section of bluefin tuna brain at level of the anterior midbrain tegmentum. Haematoxilyn-Eosin staining. Bar $=2 \mathrm{~mm}$. b) Anti sGnRH positive neurons placed in the circled zone of a). Bar $=60 \mu \mathrm{m}$. $\mathrm{mc}$, anterior cavity of mesencephalon; il, inferior lobe; ot, opticum tectum; asterisk, recessus lateralis.

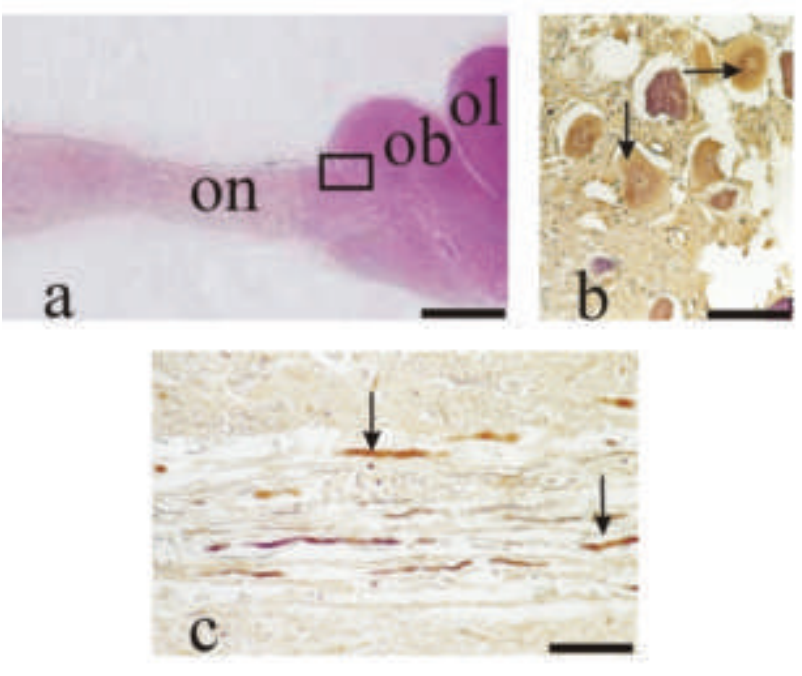

Figure 7. Light micrographs of the bluefin tuna rinencephalon. a) Low magnification micrograph of a parasagittal section showing olfactory nerve, olfactory bulb and olfactory lobe. HaematoxilynEosin staining. Bar $=3 \mathrm{~mm}$. b) Detail of the squared zone of a) showing perikarya immunostained with anti $c G n R H I I$ serum. Bar $=75 \mu \mathrm{m}$. c) Nerve fibres immunostained with anti cGnRH II serum. Bar = $60 \mu \mathrm{m}$. ob, olfactory bulb; ol, olfactory lobe; on, olfactory nerve; arrow, immuno-reactive neuronal structures. 
the rhinencephalon (Figure $7 \mathrm{a}$ ), anti $c G n R H$ and anti sGnRH sera immunoreacted with some perikarya and nerve fibres in the olfactory bulb (Figure $7 \mathrm{~b}$ ) and olfactory nerve (Figure $7 \mathrm{c}$ ). Anti cGnRH immunoreactive fibres were observed in the junction between the olfactory bulb and the olfactory lobe.

\section{Discussion}

This paper provides a morphological description of the bluefin tuna brain and the diencephalic nuclei thought to be involved in reproductive functions. Moreover, data on the immunolocalization of anti GnRH-positive neurons in the forebrain and midbrain of the species in question are also given.

The $Q E$, calculated on the basis of the brain mass to body mass ratio reported by Lisney and Collin (2006) indicates that the brain mass of the bluefin tuna is less developed than expected compared with other fish. This finding is not surprising since the above-mentioned ratio has been calculated for 14 fish species, 8 of which are teleosts and 6 sharks, the latter representative of fish with the largest and heaviest brain. When the comparison of the QE is limited to teleost fish, then our findings show a close similarity between bluefin tuna brain mass and the brains of other large pelagic species, including Coryphaena hippurus (L.), Katsuwonus pelamis (L.) and Thunnus albacares (Bonn.) (Lisney and Collin, 2006).

The observation of the gross morphology of the bluefin tuna brain shows the presence of a well developed optic tecta and a remarkably developed integration area, the corpus cerebelli. The optic tecta account for the dominant sensory brain area of large pelagic teleosts, due to the importance of vision for predation in pelagic environments ( Lisney and Collin, 2006). The great development of the corpus cerebelli in the bluefin tuna is presumably linked to the extraordinary locomotor performance of this high-speed and highly migratory fish (Altringham and Block, 1997; Safina, 1993).

The neuronal cell bodies of the diencephalon of the bluefin tuna involved in reproductive functions are grouped in two main nuclei, the nucleus preopticus-periventricularis and the nucleus lateralis tuberis. These two nuclei have already been described in the diencephalons of different teleost species, including the killifish (Fundulus heterocli- tus) (Peter et al., 1975), the goldfish (Carassius auratus) (Peter and Gill, 1975), the rainbow trout (Salmo gairdneri) (Billard and Peter, 1982) and the Atlantic salmon (Salmo salar) (Peter et al., 1991).

The nucleus preopticus-periventricularis corresponds to the periventricular preoptic nucleus described by Crosby and Woodburne (1940) and Crosby and Showers (1969). The neurosecretory activity of the nucleus preopticus in fish species has been shown both anatomically and functionally (Perks, 1969). In the goldfish, the nucleus preopticus periventricularis and the nucleus preopticus are continuous, although the latter can readily be distinguished as it stains with neurosecretory stains such as paraldehyde fuchsin (Peter and Gill, 1975). In the present study, GnRH-like neurons were immunolocalized both in the nucleus preopticus and in the nucleus periventricularis of the bluefin tuna, thus suggesting a potential neurosecretory role of the entire nucleus preopticus periventricularis.

In different teleost species, the preopticus component of the nucleus preopticus-periventricularis consists of two parts: the pars parvicellularis and the pars magnocellularis (Charlton, 1932; Crosby and Showers 1969). The pars parvicellularis consists of small cells with a lateroventral location, while the pars magnocellularis consists of large cells located posterodorsally. A characteristic neuronal organization has been highlighted in bluefin tuna: neurons of different size are present in the nucleus periventricularis proper (although the largest neurons are pre-eminent), while in the preoptic component of the nucleus preopticus-periventricularis only the smaller cell type can be found.

In the present study, the widely recognized terminology of "nucleus lateralis tuberis" was used to indicate the nucleus located in the ventral-lateral area of the diencephalon whose nervous fibres constitute the pituitary peduncle. Bradford and Northcutt (1983) recommended renaming large portions of this nucleus on a functional basis. In the goldfish (Peter and Gill, 1975) and in the killifish (Peter et al., 1975), the nucleus lateralis tuberis was divided, on a topographical basis, into pars anterior, inferior, posterior and lateralis. In the bluefin tuna, no morphological differences were observed in the neurons of the different putative parts of the nucleus lateralis tuberis, and no preferential distribution of the anti GnRH-positive neurons could be found within this nucleus. 
The results of this study have allowed the immunolocalization of the distribution of $\mathrm{GnRH}$ like structures in the brain and pituitary gland of bluefin tuna.

Eight $\mathrm{GnRH}$ variants have been identified in the brain of teleost fish, but (c) GnRH II, (s) GnRH and (sb) GnRH have been found to coexist in some perciformes and other fishes (Lethimonier et al., 2004).

Four different polyclonal antibodies against $s G n R H, c G n R H$ and sbGnRH were used. In this study three antisera (sGnRH 1667, cGnRH-II 675, cGnRH-II 6) revealed immunoreactivity in the perikarya of the oculomotor nucleus, anterior midbrain tegmentum, preopticus-periventricular and lateralis tuberis nuclei in the diencephalon, the neurohypophysis and in the junction between olfactory bulbs and telencephalon.

Surprisingly no immunoreactive structures were found with anti sbGnRH serum although sbGnRH is thought to be the most important regulator of gonadal function (Lethimonier et al., 2004; Pham et al., 2006), and sbGnRH-producing cell bodies project their axons mainly to the pituitary gland (White et al., 1995; Gonzalez-Martinez et al., 2001). This negative result is of difficult interpretation despite the fact that different dilutions and incubation times were used in the experiments carried out here. The lack of anti sbGnRH immunostaining likely depends on technical reasons, including the non-specificity of the primary antibody used, as well as likely antigen damage during the fixation and paraffin wax embedding. However, since large differences in the levels of sbGnRH have been shown among perciform fishes (Senthilkumaran et al., 1999), a possible explanation is that the bluefin tuna contains such a low amount of the sbGnRH form that it becomes undetectable to the immunostaining. Therefore, other types of studies, including RIA and in situ hybridization might be helpful in finding a solution to this still unanswered question.

cGnRH-II is expressed in all teleosts examined, including sarcopterigy and actinopterigy (reviewered by Letimonier et al., 2004). With the exceptions of the butterfly fish (O'neill et al., 1998), the European eel (King et al., 1990) and the catfish (Ngamvongchon et al., 1992), sGnRH has been detected in all teleost species from primitive fish, osteoglossiformes (Okubo and Aida, 2001; O'neill et al., 1998), to acanthopterigii (Lethimonier et al.,
2004). In many teleost fish studied, immunohistochemistry highlighted sGnRH immunoreactivity of the neurons of the anterior ventral brain (telencephalon and preoptic region), whereas the large cell bodies of the midbrain tegmentum were found to react to anti cGnRH-II serum (see Lethimonier et al., 2004).

The perikarya of the preopticus-periventricularis nucleus immunoreacted with anti sGnRH 1667, anti cGnRH-II 675 and anti cGnRH-II 6 sera. Differences in the distribution, $\%$ and size of the immunoreactive perikarya were observed. Anti sGnRH- and anti cGnRH-positive cells were mainly found in the preopticus and caudal part of periventricularis nucleus. sGnRH-immunoreactive cells comprised around $20-30 \%$ of the total whereas cGnRH-like neurons comprised around 50\%. Anti sGnRH-immunoreactive neurons were smaller than the anti cGnRH ones. The presence of GnRH neurons in the preopticus nucleus has been detected as a sGnRH variant in Cypryniformes (Yu et al., 1988; Powel et al., 1996) and Salmoniformes (Okuzawa et al., 1990; Amano et al., 1991), whereas the cGnRH-II form has been reported in midbrain tegmentum of most of the fish species studied (see Lethimonier et al., 2004 for review). In bluefin tuna, we were able to find weakly immunostained nerve fibres in both the preopticus nucleus and the neurohypophysis. This is in line with the function of the preopticus nucleus which is considered to be the main source of the innervation of the neurohypophysis (Yamamoto et al., 1998).

The nucleus the lateralis tuberis exhibited immunostaining with anti sGnRH 1667 serum in $40 \%$ of the neurons, whereas it did not react with antisera against $c G n R H$ and sbGnRH. The occurrence of $\mathrm{GnRH}$ cells in this nucleus has been observed in catfish Clarias batrachus (Subhedar and Rama Krishna, 1988; Khan et al., 1999; Sarkar and Subhedar, 2000). GnRH cells have been reported in the caudo-distal pars of neonatal platyfish (Schreibman et al., 1982).

In this study, we were able to find neurons and nerve fibres immunoreactive to $\mathrm{cGnRH}$ and $s \mathrm{G} n \mathrm{RH}$ sera in the bulbs as well as in the olfactory nerve of bluefin tuna. According to several authors, the GnRH-immunoreactive cells detected in this tract of the brain are the cells most strongly subjected to the action of pheromones (Fujita et al., 1991; Egorova et al., 2001) and are likely to be involved in fish sexual behaviour neuromodulation (Oka and 
Ichikawa, 1990; Parhar et al., 1994; Volkoff and Peter, 1999).

The presence of $\mathrm{GnRH}$ in extrahypothalamic areas, including the oculomotor nucleus and the anterior midbrain tegmentum, may be related to the modulation of behavioural responses. GnRH-containing motor nuclei are thought to be an integrative system for the modulation of sensory and behavioural functions (Munz et al., 1981; Egorova et al., 2001).

In this study, cGnRH-II- and sGnRH-immunoreactive fibres, presumably from the preoptic zone, have been found to enter the neurohypophysis of the bluefin tuna. Direct innervation of the pituitary gland by fibres of the hypothalamic $\mathrm{GnRH}$ neurons is characteristic of Osteichthyes (Muske, 1993; Schreibman et al., 1979). Our results are consistent with the observations of Magliulo-Cepriano et al. (1994) which revealed the presence of $c G n R H$ II and sGnRH forms in the pituitary gland of the platyfish. The presence of cGnRH-II and sGnRH in the bluefin tuna pituitary gland suggests that $\mathrm{GnRH}$ is involved in the release of gonadotropin in this species. However, it is worthwhile remembering that preoptic GnRH cells are related not only to gonadotropin secretion but also to the regulation of other pituitary hormones. The co-localization of GnRH binding sites with gonadotropins, somatotropin, somatolactin and prolactin cells has been demonstrated in the pejerrey (Odontesthes bonariensis) (Stefano et al., 1999, 2000).

In conclusion, the present study provides the first data on the morphology of the brain and two diencephalic nuclei thought to be involved in reproductive functions in the bluefin tuna. The immunohistochemical findings have allowed the demonstration of the presence of $\mathrm{sGnRH}$ and $\mathrm{cGnRH}$ variants. Further studies are necessary to elucidate the expression pattern of the GnRH forms during the different phases of the reproductive cycle of the bluefin tuna.

\section{References}

Altringham JD, Block BA. Why do tuna maintain elevated slow muscle temperatures? Power output of muscle isolated from endothermic and ectothermic fish. J Exp Biol 1997;200:2617-27.

Amano M, Oka Y, Aida K, Okumoto N, Kawashima S, Hasegawa Y. Immunocytochemical demonstration of salmon $\mathrm{GnRH}$ and cicken GnRH-II in the brain of masu salmon, (Oncorhynchus masou). J Comp Neurol 1991;314:587-97.

Amano M, Oka Y, Yamanome T, Okuzawa K, Yamamori K. Three
$\mathrm{GnRH}$ systems in the brain and pituitary of a pleuronectiform fish, the barfin flounder (Verasper moseri). Cell Tissue Res 2002;309:323-9.

Billard R, Peter RE. A stereotaxic atlas and technique for the nuclei of the diecepahalon of rainbow trout (Salmo gairdneri). Reprod Nutr Dev 1982;22:1-25.

Bradford MR, JR, Northcutt RG. Organization of the diencephalons and pretectum of the ray-finned fishes. In: Northcutt RG, Davis RE, eds, Fish Neurobiology. vol. 2. University of Michigan Press, Ann Arbor, Michigan, 1983, pp. 117-63.

Billard R, Peter RE. A stereotaxic atlas and technique for the nuclei of the diecepahalon of rainbow trout (Salmo gairdneri). Reprod. Nutr. Dev 1982;22:1-25.

Bradford MR, Northcutt RG. Organization of the diencephalons and pretectum of the ray-finned fishes. In: Fish Neurobiology. Vol. 2 (Northcutt R.G. and Davis R.E., eds). University of Michigan Press, Ann Arbor, Michigan 1983;117-163.

Charlton $\mathrm{HH}$. Comparative studies on the nucelus preopticus pars magnicellularis and the nuclues lateralis tuberis in fishes. J Comp Neur 1932;54:237-275.

Corriero A, Medina A, Mylonas CC, Abascal FJ, Deflorio M, Aragón $L$, et al. Histological study of the effects of treatment with gonadotropin-releasing hormone agonist ( $\mathrm{GnRHa}$ ) on the reproductive maturation of captive-reared Atlantic bluefin tuna (Thunnus thynnus L.). Aquaculture 2007;272:675-86.

Crosby EC, Woodburne RT. The comparative Anatomy of the preoptic area and the hypothalamus. Res Publ Ass Nerv Ment Dis 1940;20:52-169.

Crosby EC, Showers, MJC. Comparative anatomy of the preoptic and hypothalamic areas. In: Haymaker W, Anderson E, Nauta, WJH, eds. The Hypothalamus. Charles C Thomas, Springfield, 1969, pp. 61-135.

Doumenge F. Aquaculture of bluefin tuna. Biol Mar Medit $1996 ; 3: 258-288$.

Egorova AE, Kuzik VV, Danilova OA. Morphofunctional characteristics of gonadotropin-releasing hormone immunoreactive structures in the brain of the sturgeon (Acipenser güldenstädti) before spawning. J Evolut Bioch Physiol 2001;37:664-71.

Fujita I, Sorensen PW, Stacey NE, Hara TJ. The olfactory system, not the terminal nerve, function as the primary chemosensory pathway mediating responses to sex pheromones in male goldfish. Brain Behav Evol 1991;38:313-21.

González-Martínez D, Madigou T, Zmora N, Anglade I, Zanuy S, Zohar $Y$, et al. Differential expression of three different preproGnRH (Gonadotrophin-releasing hormone) messengers in the brain of the European sea bass (Dicentrarchus labrax). J Comp Neurol 2001;429:144-5.

Khan FA, Saha SG, Sarkar S, Subhedar N. B-endorphin like immunoreactivity in the forebrain and pituitary of the teleost (Clarias batrachus Linn.). Gen Comp Endocrinol 1999;113:290301.

King JA, Dufour S, Fontaine YA, Millar RP. Chromatographic and immunological evidence for mammalian $\mathrm{GnRH}$ and cicken $\mathrm{GnRH}$ II in eel (Anguilla anguilla) brain and pituitary. Peptides 1990;11:507-14

Lethimonier C, Madigou T, Muñoz-Cueto, JA, Lareyre JJ, Kah 0. Evolutionary aspects of $\mathrm{GnRHs}, \mathrm{GnRH}$ neuronal systems and $\mathrm{GnRH}$ receptors in teleost fish. Gen Comp Endocrinol 2004;135:1-16.

Lioka C, Kani K, Nhhala H. Present status and prospects of technical development of tuna sea-farming. Cah Op Medit 2000;47:27585.

Lisney TJ, Collin SP. Brain morphology in large pelagic fishes: a comparison between sharks and teleosts. J Fish Biol 2006;68:532-54.

Magliulo-Cepriano L, Schreibam MP, Blum V. Distribution of variant forms of immunoreactive gonadotropin-releasing hormone and beta-gonadotropins I and II in the platyfish, (Xiphophorus maculates), from birth to sexual maturity. Gen Comp Endocrinol 1994;94:135-50.

Munz H, Stumpf WE, Jennes L. LHRH system in brain of platfyfish. Brain Res 1981;21:1-13

Muske LE. Evolution of gonadotropin-releasing hormone ( $\mathrm{GnRH}$ ) neuronal system. Brain Behav Evol 1993;42:215-30. 
Mylonas CC, Zohar Y. Use of GnRHa-delivery systems for the control of reproduction in fish. Rev Fish Biol Fish 2001;10:463-91.

Mylonas CC, Bridges CR, Gordin H, Belmonte Ríos A, García A, De la Gándara $F$, et al. Preparation and administration of gonadotropin-releasing hormone agonist ( $\mathrm{GnRHa}$ ) implants for the artificial control of reproductive maturation in captive-reared Atlantic bluefin tuna (Thunnus thynnus thynnus). Rev Fish Sci 2007;15:183-210.

Ngamvongchon S, Sherwood NM, Warby CM, Rivier JE. Gonadotropin-releasing hormone from thai catfish: chromatographic and physiological studies. Gen Comp Endocrinol 1992;87:266-74.

O'neill DF, Powell JF, Standen EM, Youson JH, Warby CM, Sherwood NM. Gonadotropin-releasing hormones (GnRHs) in ancient teleosts, the bonytongue fishes: putative origin of salmon $\mathrm{GnRH}$. Gen Comp Endocrinol 1998;112:415-25.

Oka $Y$, Ichikawa M. Gonadotropin-releasing hormone (GnRH) immunoreactive system in the brain of the dwaft gourami (Colisa lalia) as revealed by light microscopic immunocytochemistry using a monoclonal antibody to common amino acid sequence of $\mathrm{GnRH}$. J Comp Neurol 1990;300:511-22.

Okubo K, Aida K. Gonadotropin-releasing hormones (GnRHs) in a primitive teleost, the arowana:phylogenetic evidence that three paralogous lineages of $\mathrm{GnRH}$ occurred prior to the emergence of teleosts. Gen Comp Endocrinol 2001;124:125-33.

Okuzawa K, Amano M, Kobayashi M, Aida K, Hanku I, Hasegawa Y, et al. Differences in salmon $\mathrm{GnRH}$ and cicken GnRH-II contents in discrete brain areas of male and female rainbow trout according to age and stade of maturity. Gen Comp Endocrinol 1990;80:11626.

Okuzawa K, Kobayashi M. Gonadotropin-releasing hormone neuronal systems in the teleostean brain and functional significance. In: Prasada $R$, Peter $R E$, eds. Neuronal regulation in the vertebrate endocrine system. Kluwer/Plenum, New York, 1999, pp. 85-100

Parhar IS, Koibuchi N, Sakai M, Iwata M, Yamaoka S. Gonadotropin-releasing hormone $(\mathrm{GnRH})$ : expression during salmon migration. Neurosci Lett 1994;172:15-8.

Perks AM. The neurohypophysis. In: Hoar WS, Randall, DJ, eds. Fish Physiology, vol. II. Academic Press, New York, 1969, pp. 111-205

Peter RE. The brain and neurohormones in teleost reproduction. In: Hoar WS, Randall DJ, Donaldson EM, eds. Fish Physiology, vol. IX. Reproduction, Part A. Academic Press New York NY. 1983 pp. 97-135.

Peter RE, Crim LW, Billard R. A stereotaxic atlas and implantation technique for nuclei of the diencephalons of Atlantic salmon (Salmo salar) parr. Reprod Nutr Dev 1991;31:167-86.

Peter RE, Gill VE. A stereotaxic atlas and technique for the forebrain nuclei of the goldfish, (Carassius auratus). J Comp Neurol 1975;159:69-102.

Peter RE, Macey MJ, Gill VE. A stereotaxic atlas and technique for the forebrain nuclei of the killifish, (Fundulus heteroclitus). J Comp Neurol 1975;159:103-28.

Pham KX, Amano M, Amiya N, Kurita Y. Distribution of three GnRHs forms in the brain and pituitary of the wild Japanese flounder (Paralicthys olivaceus). Fish Sci 2006;72:89-94.
Powel JF, Krueckl Sollins PM, Sherwood NM. Molecular forms of $\mathrm{GnRH}$ in three model fishes: rockfish, medaka and zebrafish. $J$ Endocrinol 1996;150:17-23.

Safina C. Bluefin Tuna in the West Atlantic: Negligent Management and the Making of an Endangered Species. Conserv Biol $1993 ; 7: 229-34$.

Sarkar S, Subhedar N $\beta$-endorphin and gonadotropin-relesing hormone in the forebrain and pituitary of the female catfish, (Clarias batrachus): double-immunolabeling study. Gen Comp Endocrinol 2000;118:39-47.

Schreibman MP, Margolis-Kazan H, Halpern-Sebod L. Immunoreactive gonadotropin and luteinizing hormone releasing hormone in the pituitary gland of neonatal platyfish. Gen Comp Endocrinol 1982;47:385-91.

Schreibman MP, Halpern LR, Margolis-Kazan H. Identification of luteinizing hormone-releasing hormone ( $\mathrm{LH}-\mathrm{RH})$ in the brain and pituitary gland of a fish by immunocytochemistry. J Exp Zool 1979;210:153-9.

Senthilkumaran B, Okuzawa K, Gen K, Ookura T, Kagawa H. Distribution and seasonal variations in levels of three native GnRHs in the brain and pituitary of perciform fish. J Neuroendocrinol 1999;11:181-6.

Servier AC, Munger BL. A silver method for paraffin sections of neural tissue. J Neuropath Exp Neurol 1965;24:130-5.

Stefano AV, Aldana-Marcos HJ, Affanni JM, Somoza GM. Gonadotropin-releasing hormone $(\mathrm{GnRH})$ neuronal systems in the pejerrey, Odontesthes bonariensis (Atheriniformes). Fish Physiol Biochem 2000;23:215-23.

Stefano AV, Vissio PG, Paz DA, Somoza GM, Maggese MC, Barrantes GE. Colocalization of GnRH binding sites with gonadotropins-, somatotropin-, somatolactin-, and prolactinexpressing pituitary cells of the pejerrey, Odontesthes bonariensis, in vitro. Gen Comp Endocrinol 1999;116:133-9.

Subhedar N, Rama Krishna NS. Immunocytochemical localization of LH-RH in the brain and pituitary of the catfish, (Clarias batrachus Linn.). Gen Comp Endocrinol 1988;72:431-42.

Volkoff $H$, Peter RE. Actions of two forms of Gonadotropin-releasing hormone and $\mathrm{GnRH}$ antagonist on spawning behaviour of the goldfish (Carassius auratus). Gen Comp Endocrinol 1999;116:34755.

White SA, Kasten TL, Bond CT, Adelman JP, Fernald RD. Three gonadotropin-releasing hormone genes in one organism suggest novel roles for an ancient peptide. Proc Natl Acad Sci USA. 1995;92:8363-7.

Yamamoto N, Parhar IS, Sawai N, Oka Y, Ito E. Preoptic gonadotropin-releasing hormone $(\mathrm{GnRH})$ neurons innervate the pituitary teleosts. Neurosci Res 1998;31:31-8.

Yu KL, Sherwood NM, Peter RE. Differential distribution of two molecular forms of gonadotropin-releasing hormone in discrete brain areas of goldfish (Carassius auratus). Peptides 1988;9:62530.

Zohar Y, Mylonas CC. Endocrine manipulations of spawning in cultured fish: from hormones to genes. Aquaculture 2001;197:99136. 
G. Palmieri et al. 